\title{
Effect of Intercropping and Crop Arrangement on Yield and Productivity of Late Season Maize/soybean Mixtures in the Humid Environment of South Southern Nigeria
}

\author{
U. L. Undie, D. F. Uwah \& E. E. Attoe \\ Department of Agronomy, Cross River University of Technology, Obubra Campus, Nigeria \\ Department of Crop Science, University of Calabar, Nigeria \\ E-mail: utietiang@yahoo.uk.cco
}

Received: September 14, 2011

Accepted: October 8, $2011 \quad$ Online Published: February 2, 2012

doi:10.5539/jas.v4n4p37

URL: http://dx.doi.org/10.5539/jas.v4n4p37

\begin{abstract}
Field experiments were carried out between September and December in 2007 and 2008 at Akamkpa $\left(15^{0} 15^{\prime \prime} \mathrm{N}\right.$; $\left.8^{0} 22^{\prime \prime} \mathrm{E}\right)$, Nigeria. The objective was to investigate yield and productivity of maize and soybean as sole crops and as additive mixtures (100:100) in response to five levels of nitrogen $(0,25,50,75$ and $100 \mathrm{~kg} / \mathrm{ha})$ and five crop arrangements (sole maize at 53,333 plants/ha, sole soybean at 266,666 plants/ha and maize: soybean intercrop arrangements of 1:1, 2:2 and 1:2). The trial was a split-plot design in a randomized complete block with nitrogen in main plot and crop arrangement in sub-plot, with three replications. Intercropping had no significant effect on grain yield of maize in 2007. In 2008, maize grain yield grain yield reduction in mixture was 6 percent compared to sole cropping. Soybean seed yield reduction in mixture was 32 and 43 percents in 2007 and 2008, respectively. Crop arrangement significantly influenced yield components and yield in both maize and soybean. Planting maize and soybean in 1:1, 2:2 or 1:2 arrangement had no significant effect on maize in 2007 but depressed grain yield of maize by 38,35 and 14 percents in 2008. Spatial arrangement of maize and soybean in $1: 1,2: 2$, and $1: 2$ depressed soybean yield by 51, 44 and 45 percents in 2007 and by 86,64 and 73 percents in 2008. Intercropping reduced the relative maize grain yield by only 1 percent in 2007 and from 4 to 9 percents in 2008. Soybean relative yields were from 31 to 34 percent lower than sole crop yield in 2007 and 39 to 46 percent lower in 2008. The relative yield totals for both 2007 and 2008 were well above unity, an indication that the system was highly productive. This implies that intercrops were 64, 66 and 63 percents in 2007 and 43,57 and 65 percents in 2008, more productive than the sole crops at 2:2, 1:2 and 1:1 arrangements, respectively. Late season maize and soybean may be planted in 2:2 or 1:2 arrangements to take advantage of optimum soybean seed yield and 65-100 percents of the maize grain yield in the humid South Southern Nigeria.
\end{abstract}

Keywords: Additive mixtures, Inter-cropping, Spatial arrangement, Late season maize/soybean

\section{Introduction}

Maize (Zea mays L.) is an important cereal crop in the family Poaceae. It is an important source of carbohydrate in human diet in the developing world and as animal feed worldwide. Early season maize is planted as cash crop in mixture with other crops and is harvested first from the mixture and sold as fresh maize to urban dwellers. Expansion in the cultivation of the early season maize crop in the humid Tropical Rainforest agro-ecology of South Southern Nigeria is limited by lack of appropriate technologies for preservation of the fresh harvest. The large gap between demand and supply has necessitated expansion of cultivation into the second or late rainy season in the South Southern Nigeria. Soybean (Glycine max (L.) Merrill) is a leguminous oil crop in the family Papilionaceae. It is an important source of protein for man and animals. Despite its importance, soybean is not a common crop in the farming system of the peasant farmers of the humid South Southern Nigeria. This is due to heavy rainfall which predisposes the crop to rot when grown and harvested as an early season crop (Oko et al., 2000). They have, however, shown that soybean crop can successfully be cultivated as a sole crop in the Tropical Rain Forest of Nigeria during the late planting season to take advantage of the approaching harmatan winds in the preservation of the harvest.

Growing crops in mixture is the main feature of the traditional cropping systems of the tropics (Sivaraman and 
Palaniappan, 1996). Recent research findings have shown that mixed cropping shall continue to be more profitable than sole cropping for the small scale or peasant farmers in the tropics, since it provides security in food output which is considered more important than food maximization in the developing world (Montimere et al., 1997, Brintha and Seran, 2008). The commonest crop mixtures practiced in this agro-ecology of South Southern Nigeria involve yam, cassava, maize, plantain and cocoyam as major food crops in all possible combinations, with each other, with little or no attention given to legumes in the combinations. Cereal-legume mixtures have been adjudged the most productive form of intercropping since the cereals may benefit from the nitrogen fixed in the root nodules of the legumes in the current year (Clark and Myers, 1994; Chalk, 1996, Adu-Gyamfi et al., 2007) or in the subsequent years (Mulongoy et al., 1992; Giller and Wilson, 1993). Arrangement of crops in mixture in the traditional farming systems in the humid South Southern agro-ecology of Nigeria is haphazard and without any sufficient attempt by farmers to pattern the crops for effective interception of solar energy. Spatial arrangement of intercrops is an important management practice that can improve radiation interception through more complete ground cover (Heitholt et al., 2005). There is, therefore, potential for higher productivity of intercrops when intra-specific competition is less than inter-specific competition for a limiting resource such as solar radiation (Banik and Sharma, 2009) or nutrients (Dahmarden et al., 2010). Much of the poor crop yields obtained in the developing countries may be attributed in part to improper crop arrangement with its attendant waste of environmental resources (Francis, 1989; Hulugale and Lal, 1986) and wrong intra-specific mixtures (Clark and Myers, 1994, Brintha and Seran, 2009).

Francis et al. (1982) compared corn and mung beans in 4:4, 2:2 and 1:1 alternate rows, respectively, with sole culture of the two crops in four locations over two years. In the best combination, which was $4: 4$, corn grain yield increased by 44 percent while that of beans decreased by 8 percent over their sole crop yields. Crookston and Hill (1979) evaluated sole maize and soybean with alternating single rows of maize and soybean. They recorded higher corn yields of 25 to 35 percent in the alternating single rows over sole cropping. Soybean seed yield in the single rows reduced by 22 to 35 percent compared to the sole crop yield. Maize seed yields in wider rows of $12: 12,6: 6$ or 3:3, were not significantly different. There was, however, a significant reduction in soybean yields over sole crop yields in all the arrangements. Montha and De (1980) recommended one row of maize alternating with two rows of soybean and alternating single rows of sorghum and soybean as the best arrangements for the cultivation of the two cereals with soybean. Some other reports also indicated that planting two rows of soybean after one row of maize was the best arrangement over single alternate rows (Ofori and Stern, 1987; Clement et al., 1992, Ullah et al., 2007). A wide range of other legume-maize intercrops have been found to respond better to two rows of legume after one row of maize (Odhiambo and Ariga, 2001; Marer et al., 2007; Banik and Sharma, 2009). With sorghum, Chiezey et al. (2005) reported that crop arrangement had no significant effect on 100-seed weight of soybean and 1000-seed weight of sorghum, but obtained more pods per plant in soybean at alternate row arrangement. Since crop arrangement is a function of plant density, there is therefore, higher light interception at wider spacing than at narrower spacing (Keating and Carberry, 1993; Prasad and Brook, 2005; Jiao et al., 2008).

Total system biological productivity is assessed by land equivalent ratio (LER). Land equivalent ratio was first defined as the relative land area required as sole crops to produce the yields achieved in intercropping (Mead and Willey, 1980). Land equivalent yield values could also be thought of as relative yields. It combines the yields of two or more unlike crops into one index for comparison with sole culture of or among intercrop systems.

Francis et al. (1986) reviewed productivity of mixtures in different strip crop rows from Illinois, Minnesota and Pennsylvania. For corn-soybean strip cropping the ratio ranged from 0.95 to 1.15 , while that for corn-Phaseolus beans were between 1.01 and 1.18. The review showed that the strip cropping were as much as 5 percent less efficient and up to 18 percent more efficient compared to sole culture of these crops. Crookston and Hill (1979) studied various row arrangements of maize-soybean intercropping in Minnesota and reported land equivalent ratios ranging from 0.97 to 1.02, though with no significant increase in grain yield. Ayisi et al. (1997) reported significant row arrangement effect on the productivity of canola-soybean. Narrow strips of one to four metres width gave land equivalent ratios significantly greater than unity (1.02 to 1.65). Nguimgo et al. (2003) obtained land equivalent ratios of more than unity in either maize-groundnut or maize-soybean intercropping when no nitrogen was applied. Odhiambo and Ariga (2001) obtained LER of 1.6 in maize-bean intercrop, while Marer et al. (2007) obtained LER of 1.52 in maize-pigeon pea mixture. For any yield advantage to be achieved from a mixture, the lower component crop must be patterned in such a way as to intercept at least 50 to 75 percent of light (Keating and Carberry, 1993).

The performance of an additive or superimposed population of maize and soybean grown as late season intercrops has not been investigated in this area. In view of the above reasons, this research was undertaken with 
the objectives of evaluating the effect of intercropping and crop arrangement on yield attributes and yield of late season maize-soybean intercrop, and to determine the best row arrangement for maize-soybean intercropping in the humid South Southern agro-ecology of Nigeria.

\section{Materials and Methods}

Field experiments were conducted in September to December of 2007 and 2008 to study the effect of nitrogen application, intercropping and crop arrangement on yield and yield components of late season maize/soybean intercropping. The study was sited at the Teaching and Research Farm of the Cross River University of Technology, Akamkpa. Akamkpa $\left(5^{0} 15^{\prime \prime} \mathrm{N} ; 8^{0} 22^{\prime} \mathrm{E}\right)$ lies in the tropical rainforest agro-ecology of the Equatorial climatic belt of Nigeria. The mean annual temperature of the area ranges between $23^{\circ} \mathrm{C}$ to $35^{\circ} \mathrm{C}$ with daily range of about $3^{\circ} \mathrm{C}$. The area has distinct wet and dry seasons with mean annual rainfall ranging from 1,250 to 4,000 $\mathrm{mm}$. The wet season has double rainfall peaks during July and October with a short break in rainfall called "August break" in between the double peaks (Iwena, 2008). Consequently, there are two cropping seasons (early: from March to July, and late: from August to December) in the area.

The soils of Akamkpa are formed from Basement complex, predominantly granite and gneiss, and are classified as dystic cambisol. The soils are fine, granular and sandy loam in texture and are well-drained (Ibanga et al., 1989). The 2007 experimental site was under cassava cultivation for five years but left fallow for one year before the commencement of the experiment. The site had Aspilia africana (L.) and guinea grass, Panicum maximum Jacq. as predominant weeds. The 2008 experimental site was under yam cultivation for one year and was fallowed for two years before the start of the experiment. The predominant weeds were Chromolaena odorata (L.) and Mucuna spp.

Hybrid maize (OBA SUPER 2) and soybean (TGX 1440-IE) cultivar were used for the experiment. OBA SUPER 2 is yellow coloured maize developed by Premier Seed, Nigeria Limited of Chikayi Industrial Estate, Zaria. The seeds were obtained from the National Seed Service, Umudike. The hybrid maize was selected on the basis of its high yield, adaptability to the climatic zone and its resistance to diseases, especially striga, but the hybrid crop is yet to be widely accepted and grown with or as a replacement for the traditional white maize varieties in this agro-ecology. TGX 1440-IE is a cream coloured soybean cultivar of medium maturity (90-120 days). The variety was obtained from the Department of Agronomy, Michael Okpara University of Agriculture, Umudike. The variety has been recommended for cultivation in the Rain Forest agro-ecology due to its high yield and promiscuity (Okpara and Ibiam, 2000).

The experimental treatments consisted of five nitrogen levels $(\mathrm{O}, 25,50,75$ and $100 \mathrm{~kg} \mathrm{~N} / \mathrm{ha})$ and five crop arrangements. The arrangements were sole maize, sole soybean and maize: soybean intercrop arrangements of 1:1, 2:2 and 1:2, respectively. The treatment combinations were assigned to a split plot design in a randomized complete block with three replications. The five rates of nitrogen were randomly assigned to the main plots while the five types of crop arrangements were randomly allocated to the subplots. The gross main plot size was $3 \mathrm{~m} x$ $10 \mathrm{~m}\left(30 \mathrm{~m}^{2}\right)$, while the subplot size was $3 \mathrm{~m} \mathrm{x} 2 \mathrm{~m}\left(6 \mathrm{~m}^{2}\right)$. The net plot size for data collection was $1 \mathrm{~m} \times 1.5 \mathrm{~m}$ $\left(1.5 \mathrm{~m}^{2}\right)$.

Composite soil sample obtained with a soil auger from a depth of 0-30 cm prior to fertilization was analyzed in the Soil Science Laboratory of the Department of Soil Science, University of Calabar, Calabar, in both 2007 and 2008. Particle size analysis was determined by the hydrometer method using sodium hexametaphosphate (Calgon) solution as outlined by Juo (1979). The textural class was determined by the use of standard textural triangle. Soil samples for chemical analysis were air dried and ground to pass through a $23 \mathrm{~mm}$ sieve for the subsequent procedures and analyses. Soil $\mathrm{pH}$ was measured with a glass electrode $\mathrm{pH}$ meter in soil water suspension of 1:2.5 and organic carbon was determined by the Walkley and Black wet oxidation methods as given in Juo (1979). Total soil nitrogen was determined by the macro-kjedahl method of Bremmer (1965). Available P was determined by the method of Murphy and Riley (1965). Phosphorus was determined calorimetrically using molybdenum blue. Calcium and magnesium were estimated by the Versenate EDTA Titration method (Juo, 1979), while exchangeable K and Na were estimated by flame photometry (Juo, 1979). The exchangeable cations were determined on extracts obtained after leaching soil samples with neutral normal ammonium acetate solution.

The temperature and rainfall data for 2007 and 2008 cropping years were obtained from the Nigeria Meteorological Services (NIMET), Margaret Ekpo International Airport, Calabar. In each year, the experimental site was cleared, ploughed and raked to give a uniform and smooth planting surface. Plots in a replication were separated from each other by $1.5 \mathrm{~m}$ path. The 2007 crops were planted on 22nd September, 2007 while the 2008 crops were planted on 5th September, 2008. Three seeds of each crop were sown manually per hole using a 
meter tape to achieve the desired distances. The seedlings were thinned to one plant per stand at one week after sowing. There were no missing stands. Interplant spacing was maintained at $25 \mathrm{~cm}$ throughout for maize and 5 $\mathrm{cm}$ for soybean except in 1:2 arrangement where it was $10 \mathrm{~cm}$. The crops were sown as sole maize (M) or sole soybeans (S) and three arrangements of maize and soybean intercropping of 1 row maize to I row soybean (1:1), 2 rows maize to 2 rows soybean (2:2) and I row maize to 2 rows soybeans (1:2). An additive or superimposed model was used and plant density was kept constant on a total plot area basis set at the optimum for sole crops and kept the same in intercrops. Maize was planted at 53,333 plants/ha and soybean at 266,666 plants/ha by adjusting within row spacing of the intercrops.

Rows were spaced $75 \mathrm{~cm}$ apart in sole maize and in sole soybean plots. Intercropped maize was $75 \mathrm{~cm}$ from maize to maize and $37.5 \mathrm{~cm}$ from maize to soybean rows in $1: 1$ arrangement; but $37.5 \mathrm{~cm}$ from maize to maize or maize to soybean in 2:2 arrangement. In 1:2 arrangement, intercropped maize was $75 \mathrm{~cm}$ from maize to maize but $25 \mathrm{~cm}$ from maize to soybean. Intercropped soybean rows were $75 \mathrm{~cm}$ from soybean to soybean and $37.5 \mathrm{~cm}$ from soybean to maize rows in $1: 1$ arrangement but $37.5 \mathrm{~cm}$ from soybean to soybean or soybean to maize in 2:2 arrangement. However, in 1:2 arrangement, intercropped soybean was $25 \mathrm{~cm}$ from soybean to soybean or soybean to maize.

Phosphorus as single superphosphate (7.8 percent $\mathrm{P})$ and potassium as muriate of potash (49.8 percent $\mathrm{K})$ were applied at the rates of $30 \mathrm{~kg} \mathrm{P} / \mathrm{ha}$ and $50 \mathrm{~kg} \mathrm{~K} / \mathrm{ha}$. The two fertilizers were uniformly broadcast and harrowed into the soil before planting. Nitrogen was applied as urea ( 46 percent $\mathrm{N})$ at the rates as per each treatment. Half of the required dosage was applied two weeks after sowing and the remaining half was applied six weeks after sowing, all by side placement along the rows. Weeds were controlled post emergence by manual weeding with hoe at 4 and 8 weeks after sowing.

The 2007 maize and soybeans crops were harvested together on 15th December, 2007 (81 days after sowing) while the 2008 crops were harvested on 24th December, 2008 (110 days after sowing). In both years, harvesting was done manually when the maize and the soybean had reached physiological maturity. In 2007, earlier harvesting was due to earlier cessation of rainfall and subsequent dry up of the maize crop. Crop data were taken randomly from crops within the net plot measuring $1.5 \mathrm{~m}^{2}$. Ten plants of maize and twenty soybean plants were taken per plot for crop attributes and for yield measurements and computations.

The following data were collected for maize:

Cob length: This was measured with a meter tape from the base to the tip of the cob and recorded in centimetres.

Cob diameter: This was taken with vernier calipers half way between the tip and the base of the cob and recorded in centimetres.

100-grain weight: This was determined by counting seeds from each yield sample used for grain yield. A total of 300 oven dried seeds were counted by hand, weighed and then divided by three.

Shelling percentage: This was calculated from the 10-plant sample as (seed weight/cob weight) $\mathrm{x} 100$.

Cob yield: Cobs were dried in the oven at $60^{\circ} \mathrm{C}$ until three consecutive constant weights were obtained. The cobs were then weighed with an electronic scale and the weight recorded and calculated in $\mathrm{kg} / \mathrm{ha}$.

Grain yield: This was determined by drying the seeds from each yield sample to a constant weight at $60^{\circ} \mathrm{C}$ in an oven, weighing the sample and then calculating grain yield in $\mathrm{kg} / \mathrm{ha}$.

Harvest index: This was calculated from the ten-plant sample as (seed weight/total sample weight) $\mathrm{x} 100$.

The following data were taken for soybean:

Number of pods per plant: This was counted and recorded as mean number of pods borne by plants in a sample at maturity.

Percentage sterile pods per plant: This was estimated as (pods with no seed/pods with at least one or more seeds) $\mathrm{x} 100$.

Pod yield: Hand threshed and oven dried pods were weighed separately and the weight of the pod samples was added to the corresponding weight of their oven dried seeds and calculated as pod yield in $\mathrm{kg} / \mathrm{ha}$.

Seed yield: Seeds from each sample were dried in an oven at $60^{\circ} \mathrm{C}$ to a constant weight and the recorded weight calculated as grain yield in $\mathrm{kg} / \mathrm{ha}$.

Shelling percentage: This was estimated as (seed weight/total pod sample weight) $\mathrm{x} 100$.

All the data collected were subjected to statistical analysis appropriate to the split plot design in a randomized 
complete block using Windows Statistical Package for Social Sciences (SPSS), Version 14. Analyses of variance (ANOVA) were constructed to examine nitrogen effect and its interaction on the variables measured. Treatment means were separated and compared using Duncan's Multiple Range Test (DMRT) at $5 \%$ probability level (Gomez and Gomez, 1984).

\section{Assessment of mixed cropping by relative yield totals (RYT)}

This was taken as an accurate assessment of biological efficiency of competition under intercropping situation where land equivalent ratio (LER) was compared at uniform overall plant density of the sole and intercrops (Subbian et al., 2006). This is given as:

$$
\mathrm{RYT}={ }^{\mathrm{n}} \sum_{\mathrm{j}-\mathrm{i}} \mathrm{Yab}+\mathrm{Yba} / \mathrm{Yaa}+\mathrm{Ybb}
$$

Where:

$$
\begin{aligned}
& \text { Yaa }=\text { yield of component ' } a \text { ' in pure stand } \\
& Y b b=\text { yield of component ' } b \text { ' in pure stand } \\
& Y a b=\text { yield of component ' } a \text { ' in intercrop with component ' } b \text { ' } \\
& Y b a=\text { yield of component ' } b \text { ' in intercrop with component ' } a \text { ', }
\end{aligned}
$$

\section{Results and Discussion}

Results of the physical and chemical properties of the experimental sites are presented in Table 1. The results showed that the two sites were sandy loam in texture. However, the site for 2007 experiment was lower in total nitrogen $(0.09$ percent $)$ compared to the 2008 site $(0.13$ percent). Generally, the 2007 site was lower in all the nutrient elements measured, as well as in base saturation. The soil acidity was, however, higher in 2007 site compared to 2008 site. The average monthly minimum and maximum temperatures of the agro-ecology of the experimental site are presented in Table 2. There was little variation in temperature between the months in either 2007 or 2008. The sowing month of September in both the years was warmer than the previous month. The highest temperatures occurred in December in both the years which were ideal for ripening and harvesting of the crops. The average monthly rainfall showed marked variation in each of the years. In 2007, the average rainfall during planting in September was higher $(561.7 \mathrm{~mm})$ compared to $2008(122.5 \mathrm{~mm})$. The average rainfall during harvest (December) in 2007, on the other hand, was lower $(33.1 \mathrm{~mm})$ compared to 2008 (77.1 mm). Treatment effects of the two crops are presented below. Due to significant interaction between nitrogen and crop arrangements, all the crop arrangement results were averaged over nitrogen and reported as separate result.

\subsection{Cob Length and Cob Diameter in Maize}

In both 2007 and 2008, the sole maize produced the longest cobs than any of the intercrop arrangements, while among the intercrop arrangements, the 1:1 produced the shortest cobs (Table 3). However, the cob length difference between the sole crop and 1:2 or 2:2 and 1:2 arrangements in 2007 or 2:2 and 1:2 arrangements in 2008 were not significantly different.

The effect of intercropping on cob diameter of maize was significant in 2008 but not in 2007 (Table 3). In 2008, the sole crop gave the highest cob diameter which was significantly higher than those obtained either at 1:1, 2:2 or $1: 2$ arrangements by $5.3,3.2$ and $3.7 \%$, respectively. Crop arrangement had no significant effect on cob diameter in maize in 2008.

\subsection{Number of Cobs per Plant and 100-grain Weight in Maize}

Intercropping and crop arrangement significantly affected the number of cobs per plant in both 2007 and 2008 (Table 4). In both years, the number of cobs produced by the sole maize was significantly higher than that obtained by any of the intercrop arrangements. Among the intercrop arrangements, the 1:1 consistently and significantly produced the lowest number of cobs per plant than either the 2:2 or 2:1. The number of cobs per plant obtained at 2:2 and 1:2 arrangements were, however, not significantly different in both years.

Intercropping and crop arrangement had no significant effect on 100-grain weight in 2007 (Table 4). In 2008, the sole crop produced significantly higher 100-grain weight than any of the arrangements. Among the arrangements the 1:1 significantly produced the lowest weight, while that at 2:2 and 1:2 were statistically at par.

\subsection{Grain Yield and Cob Yield in Maize}

Intercropping and crop arrangement had no significant effect on grain yield of maize in 2007 (Table 5). In 2008, the sole crop produced significantly the highest grain yield than any of the intercrop arrangements. Grain yield produced by the sole maize was $9.5,3.6$ and $4.9 \%$ higher than that obtained at 1:1, 2:2 and 1:2 arrangements, 
respectively. Among the intercrop arrangements, the 1:1 produced the lowest grain yield which was significantly lower than that obtained at 2:2 or 1:2 arrangements.

Intercropping and crop arrangement had no significant effect on cob yield in 2007 (Table 5). In 2008, the sole crop produced significantly higher cob yield compared to 2:2, 1:2 or. Among the crop arrangements, the 1:1 crop arrangement produced significantly the lowest yield. The cob yields of 2:2 and 1:2 crop arrangements were, however, significantly higher than that of 1:1 arrangement.

\subsection{Harvest Index and Shelling Percentage in Maize}

Intercropping maize with soybean significantly affected its harvest index both in 2007 and 2008 (Table 6). In both years, the sole maize produced significantly higher harvest index than any of the intercrop arrangements. Among the different crop arrangements, the harvest indices obtained in 2007 were not significantly different. In 2008, the harvest indices at 1:1 and 2:2 arrangements were also not significant but both were significantly higher than the value obtained at 1:2 arrangement.

Intercropping and crop arrangement had no significant effect on shelling percentage of maize in 2007 (Table 6). In 2008 , however, the shelling percentage obtained by the sole crop was higher than the values obtained at any crop arrangement but not significantly different to $2: 2$ or 1:2 arrangements. The shelling percentage of 2:2 or 1:2 crop arrangements were statistically similar.

\subsection{Number of Pods per Plant and Percentage Sterile Pods in Soybean}

The number of pods per plant in soybean was significantly influenced by intercropping and crop arrangement in both 2007 and 2008 (Table 7). In each of the years, the highest numbers of pods were produced by the sole crop. Among the intercrop arrangements, the number of pods per plant obtained at 2:2 and 1:1 were statistically the same both in 2007 and 2008.

The effect of intercropping and crop arrangement on percentage sterile pods was also significant in 2007 and 2008 (Tables 7). The result showed that the sole soybean crop produced the least sterile pods in both years and these were significantly lower than those produced by any of the intercrop arrangements. Among the intercrop arrangements, the sterile pods obtained at 1:1 was significantly higher than those obtained at any other arrangement, while those obtained at 2:2 and 1:2 arrangements were not significantly different.

\subsection{0-seed Weight and Grain Yield in Soybean}

Intercropping and crop arrangement both significantly affected 1000-seed weight in 2007 and 2008 (Table 8). The result indicated that the highest 1000-seed weight was obtained by the soil crop in both years. Among the intercrop arrangements the lowest 1000- seed weight was obtained at 1:1 in 2007 and 1:1 or 2:2 in 2008. The 1000 -seed weights obtained at 2:2 and 1:2 arrangements in 2007 or 2:2 and 1:1 arrangements in 2008 were statistically similar.

Intercropping and crop arrangement differently affected grain yield in soybean in 2007 and 2008 (Table 8). In 2007 , the sole soybean produced significantly higher grain yield (45\%) than the best intercrop arrangement, while grain yields obtained among the different intercrop arrangements were not significantly different. In 2008, grain yield obtained by the sole crop was statistically higher than that of the 1:1, 2:2 and 1:2 intercrop arrangements by 86,64 and $74 \%$, respectively. Similarly, grain yield differences among all the intercrop arrangements were also significant.

\subsection{Pod Yield and Shelling Percentage}

Intercropping had significant effect on pod yield of soybean in 2007 and 2008 (Table 9). In both years, the sole soybean produced significantly higher pods than all the intercrop arrangements. Intercrop arrangements had no significant effect on pod yield in 2007. In 2008, pod yield at 1:2 arrangement was significantly the highest, followed by 2:2 arrangement. Pod yield obtained at 1:1 arrangement was significantly the lowest.

The effect of intercropping on shelling percentage of soybean was also significant in 2007 and 2008 (Table 9). The sole soybean produced significantly higher shelling percentage than 1:1, 2:2 or 1:2 crop arrangements in both years, but the shelling percentages obtained at all the intercrop arrangements in 2007 were not significantly different. Among the intercrop arrangements in 2008, shelling percentages obtained at 2:2 arrangement was significantly the highest, while that obtained at 1:1 arrangement was significantly the lowest.

\subsection{Assessment of Mixed Cropping}

The relative yields and relative yield totals for maize and soybean grown sole and in mixture are presented in Table 10. The results indicated that intercropping maize with soybean either at 2:2, 1:2 or 1:1 arrangement did 
not produce any significant difference in the relative yield of maize in 2007. In 2008, however, the relative yields of maize at 2:2, 1:2 and 1:1 arrangement varied from 0.97 in 2:2 arrangement to 0.95 and 0.91 in 1:2 and 1:1 arrangements, respectively.

In soybean, there was no difference in the relative yields obtained at 2:2 and 1:2 arrangements in 2007. Each had a relative yield of 0.69 . The relative yield of 0.66 obtained at 1:1 arrangement was the lowest in 2007. In 2008, soybean relative yield was highest at 2:2 crop arrangement ( 0.61$)$, followed by 1:2 crop arrangement $(0.58)$. The lowest relative yield in 2008 was again obtained at 1:1 arrangement $(0.54)$. In the combined analysis, the same trends as in separate analyses were observed. The relative yield totals for all the crop arrangements in both years and in the combined analysis were well above unity. In 2007, 2:2 and 1:2 arrangements had similar relative yield totals of 1.68 compared to 1.65 obtained at 1:1 arrangement. In 2008, the 2:2 arrangement produced the highest relative yield total (1.58), followed by 1:2 crop arrangement (1.52) and the lowest was obtained at 1:1 arrangement (1.45). The highest average relative yield total occurred at 2:2 crop arrangement with the lowest obtained at 1:1 crop arrangement.

Yield components of both maize and soybean in mixture were affected relative to components in sole cropping. In maize, the yield attributes of number of cobs per plant and cob length were consistently and significantly depressed in mixture compared to sole cropping in each of the years. Cob yield, shelling percentage, 100-grain weight and cob diameter in maize were significantly reduced in mixture, but there was no significant response in these attributes to intercropping in 2007. The differential response between the years might be attributed to late planting, shorter duration and therefore less vegetative growth in 2007, which adversely affected the performance of the maize crop both in mixture and as sole crop. Reduction in these yield attributes in mixture compare to sole cropping, especially in soybean, was expected and might be as a result of intra-and inter-specific shading. The naturally taller maize tended to shade the shorter soybean when grown in mixture particularly because the populations were additive.

The number of sterile pods in soybean in this study increased appreciably in mixtures compared to sole cropping, and these increases were 13,14 and 34 percents in 2007, and 18, 21 and 35 percents in 2008 at 1:2, 2:2, and 1:1 arrangements, respectively (Table 7). More empty pods in intercropping compared to sole cropping might be due to competition and shading effects on the soybean by the taller maize. The resultant high percentage sterile pods nullified any gain in grain yield that could have been achieved in mixtures.

Maize grain yield was not significantly affected by intercropping in 2007 (Table 5). In 2008, maize grain yield was clearly depressed in intercropping compared to sole cropping. Average grain yield reduction in mixture compared to sole cropping was 6 percent. However, soybean grain yield in mixture was depressed in both years compared to its sole crop yields (Table 8). Average seed reduction in mixtures was 32 and 43 percents in 2007 and 2008, respectively, which might be attributed to intra- and inter- specific shading effects. Fisher (1980) obtained no significant difference in grain yield between sole maize and intercropped maize, a situation similar to our result in 2007. On the other hand, Gunasena et al. (1979) and Dalal (1977) obtained various increases in grain yield of maize in mixture over sole crop yields. Nguimgo et al. (2003) reported that the grain yield of maize in mixture was reduced compared to its sole crop yield, a situation similar to our result in 2008. Similarly, Abayer (1984) noted 20 percent reduction in grain yield of sorghum in mixture with soybean compared to its sole crop yield. Simultaneous reduction in grain yield of the components in mixture as observed in this study in 2008 has been reported by Anon (1974) in maize/pigeon pea mixture, Enyi (1973) in maize/cowpea/ bean mixtures and Ennin et al. (2002) in maize/soybean mixture.

Among the intercrops, grain yield in response to crop arrangement varied between 2007 and 2008. In 2007, crop arrangement had no effect on grain yield in intercropped maize and soybean (Tables 5 and 8). However, in 2008, crop arrangement influenced grain yield of maize and soybean differently. Planting maize and soybean in 1:1 (single alternate) arrangement depressed grain yield of maize by 5.4 percent, and soybean by 11.9 percent over the grain yield of the best arrangement of 2:2. Similarly, grain yield depression at 1:2 arrangement was 1.3 and 5.7 percents for maize and soybean, respectively, over that obtained at 2:2 arrangement. The 2:2 arrangement was, therefore, the best arrangement in this study, followed by the 1:2 arrangement. These trends are similar to those reported for early season crops by Ofori and Stern (1987), Clement et al. (1992), Ennin et al. (2002), Silwana et al. (2007) and Ullah et al. (2007) that 2 maize rows: 2 soybean rows or 1 maize row: 2 soybean rows resulted in more grain yield than planting the crops in single alternate rows. Since the populations in each of the arrangements were the same, any yield difference in this study might be attributed to plant arrangement effect, thus, better resources utilization as reported by Keating and Carberry (1993), Ennin et al. (2002) and Banik and Sharma (2009). 
Intercropping reduced the relative grain yield in maize by only 1 percent in 2007 and from 4 to 9 percents in 2008 (Table 10). Soybean had higher reductions in relative grain yield than maize due to shading effects, a situation similar to that reported by other workers (Ennin et al., 2002; Silwana et al., 2007). Soybean relative yields were from 31 to 34 percents lower than sole crop yield in 2007 and 39 to 46 percents lower in 2008. The higher relative yield reduction in 2008, compared to 2007, might be due to higher vegetative growth of maize and, consequently, higher shading effect on the soybean component.

The relative yield totals for both 2007 and 2008 were well above unity, an indication of high productive system. This implies that intercrops were 64, 66 and 63 percents in 2007 and 43, 57 and 65 percents in 2008, more productive than the sole crops at 2:2, 1:2 and 1:1 arrangements respectively. The 2:2 arrangement with the highest relative yield total in both years was, therefore, considered the best intercrop arrangement followed by 1:2 arrangement for intercropping maize and soybean in the humid South Southern agro-ecology of Nigeria. The narrow margins in the relative yield totals between the three different arrangements were expected as the populations were additive and kept constant in each of the intercrop arrangements.

Reports from other studies on the effect of crop arrangement on intercrop productivity have been conflicting. Similar to our result were reports of increased intercrop productivity in maize/soybean (Francis et al., 1985; Montha and De, 1980; Clement et al., 1992; Ullah et al., 2007), but contrasting with the present study were reports of decreased intercrop productivity with crop arrangement in maize/soybean (Ennin et al., 2002) and canola/soybean (Ayisi et al., 1997), or no significant effect in sorghum /soybean (Chiezey et al., 2004). From the results obtained in our study, it is evident that the high total population density and the associated intra-specific and inter-specific competition resulting from the super-imposed (100:100) sole crop population of soybean on maize and late planting may have contributed to the observed trend in yield attributes, yield and productivity of the intercrops at the different crop arrangements.

\section{Conclusion}

This study demonstrated the role of additive or superimposed populations and crop arrangement on yield and yield components of late season maize, soybean and maize/soybean intercropping in the humid agro-ecology of Nigeria. These findings have significant implications in physiological studies such as crop modeling for more efficient leaf architecture of each component crop in future breeding work, and best management practices for grain production through modified planting pattern and population densities of late season intercrops as opposed to early season crops. Farmers in this agro-ecology can therefore superimpose sole crop populations to intercrop maize and soybean at the spacing of 2 rows of maize to 2 rows of soybean for the extra benefits associated with this system.

\section{References}

Abayer, M. I. (1984). The effect of nitrogenous fertilizer on the grain yield of sorghum and soybean. M.Sc Thesis, Department of Agronomy, Ahmadu Bello University, Zaria, Nigeria.

Adu-Gyamfi,J.J., F.A. Myaka, W.D. Sakala, R. Odgaard, J.M. Vesterager \& H. Hogh-Jensen. (2007). Biological nitrogen fixation and nitrogen and phosphorus budgets in farmer-managed intercrops of maize-pigeonpea in semi-arid Southern and Eastern Africa. Plant Soil, 295, 127-136. http://dx.doi.org/10.1007/s11104-007-9270-0

Anonymous. (1974). Notes on the Experimental Cropping Systems Improvement Programme. Cropping Scheme Meeting. Ahmadu University, Zaria.

Ayisi, K. K., D.H. Putman, C.P. Vance, M.P. Russela \& D.L. Allan. (1997). Strip cropping and nitrogen effects on seed, oil and protein yields of canola and soybean. Agronomy Journal, 89, 23-29. http://dx.doi.org/10.2134/agronj1997.00021962008900010004x

Banik, P. \& R.C. Sharma. (2009). Yield and resource utilization efficiency in baby corn-legume intercropping system in the eastern plateau of India. Journal of Sustainable Agriculture, 33, 379-305. http://dx.doi.org/10.1080/10440040902834970

Bremmer, J. M. (1965). Total nitrogen. In: Black, C. A. (editor). Methods of Soil Analysis. Part 2:1149. Pages 511 - 576. America Society of Agronomy. Madison, Wisconsin.

Brintha, I. \& T.H. Seran. (2008). Financial analysis of different cropping systems of Brinjal (Solanum melongena L.) intercropped with Groundnut (Arachis hypogaea L.). Proceedings of the National Symposium, October 23, Faculty of Agriculture, University of Ruhuna, Sri Lanka, pp: 83. 
Brintha, I. \& T.H. Seran. (2009). Effect of paired row planting of radish (Raphanus sativusL.) intercropped with vegetable amaranthus (Amaranthus tricolor L.) on yield components of radish in sandy regosol. Journal of Agricultural Science, 4, 19-28.

Chalk, P. M. (1996). Nitrogen transfer from legumes to cereals in intercropping. In: Proceedings of the International Workshop: Dynamic of Roots and Nitrogen in Cropping systems of the Semi-Arid Tropics (ICRISAT), Pages 351-374. Patancheru, Andhra Pradesh, 21-25 November.

Chiezey. U. F., I.M. Haruna \& E.C. Odion. (2004). Growth and development of sorghum/soybean mixture with nitrogen, phosphorus and plant arrangement in the northern Guinea Savanna ecological zone of Nigeria. Crop Research, 28, 1-14.

Chiezey. U. F., I.M. Haruna \& E.C. Odion. (2005). Productivity of sorghum/soybean mixture and influence of N, $\mathrm{P}$ and plant arrangement in the Northern Guinea Savanna zone of Nigeria. Crop Research, 29, 1-14.

Clark, K. M. \& R.L. Myers. (1994). Intercrop performance of pearl millet, amaranth, cowpea, soybean and guar in response to planting pattern and nitrogen fertilizer. Agronomy Journal, 86, 1097-1102. http://dx.doi.org/10.2134/agronj1994.00021962008600060032x

Clement, A., F.P. Chalifour, F. P., M.P. Bharati \& G. Gendrin. (1992). Effects of nitrogen supply and spatial arrangements on the grain yield of maize/soybean intercrop in humid subtropical climate. Canadian Journal of Plant Science, 72, 57-67. http://dx.doi.org/10.4141/cjps92-007

Crookston, R. K. \& D.S. Hill. (1979). Grain yields and land equivalent ratios from intercropping corn and soybeans in Minnesota. Agronomy Journal, 41 .44. http://dx.doi.org/10.2134/agronj1979.00021962007100010010x

Dalal, R. C. (1977). Effect of intercropping maize with soybean on grain yield. Tropical Agriculture, 54, 189-191.

Ennin, S. A., M.O. Clegg \& C.A. Francis. (2002). Resource utilization in soybean/maize intercrops. African Crop Science Journal, 10(73), 251-261.

Enyi, B. A. (1973). Effect of intercropping maize or sorghum with cowpea, pigeon peas or beans. Experimental Agricultural, 9, 83-90. http://dx.doi.org/10.1017/S0014479700023711

Fisher, N. N. (1980). A note on agronomic research with soybean at the Institute for Agricultural Research, Ahmadu Bello University, Zaria. In: Proceedings of the First National Meeting of the Nigerian Soybean Scientists, International Institute for Tropical Agriculture,Ibadan, Nigeria. November 1980.

Francis, C. A. (1989). Biological efficiencies in multiple-cropping systems. Advances in Agronomy, 42, 1-42. http://dx.doi.org/10.1016/S0065-2113(08)60522-2

Francis, C. A., T.C. Barker, S. Goodman, S. \& K.Wittler. (1985). Strip cropping potentials for corn and grain legumes. Agronomy Abstract, Page 96.

Francis, C. A., A. Junes, K. Crookston, K. Whittler \& S. Goodman. (1986). Strip cropping potentials for corn and grain legumes: a review. University of Nebraska Journal Series. Number 822 (4), 159-164.

Francis, C. A., M. Prager \& G. Tejada. (1982). Density interactions in tropical intercropping maize (Zea mays L.) and mung beans (Phaseolus vulgaris L.). Field Crops Research, 5(2), 163-175. http://dx.doi.org/10.1016/0378-4290(82)90016-8

Giller, K. E. \& K.J. Wilson. (1993). Nitrogen Fixation in Tropical Cropping Systems CAB International, Wallingford, U. S. A.

Gomez, K. A. \& A.A. Gomez. (1984). Statistical Procedures for Agricultural Research. John Wiley and Sons, New York.

Gunasena, H., R. Sangakkara \& P. Wickrema-Singh. (1979). Studies on cereal-legume intercropping systems. Journal of National Science Council of Sri Lanka, 7, 85-93.

Heitholt, J. J., J.B. Farr \& R. Eason. (2005). Plant configuration and cultivar environments. Crop Science, 45, 1800-1808. http://dx.doi.org/10.2135/cropsci2004.0603

Hulugale, N. R. \& R. Lal. (1986). Soil water balance of intercropped maize and cowpea grown in a tropical hydropmorphic soil in Western Nigeria. Agronomy Journal, 77, 86-90. http://dx.doi.org/10.2134/agronj1986.00021962007800010019x 
Ibanga, J. J., L. Lekwa, U.C. Ekoo, M.N. Annon, T. Udo-Isong, T.O. Ugwu, \& C. Ahumile. (1989). Soil and Land Use Survey of Cross River State, Cross River State Ministry of Agriculture and Natural Resources/ Main Bulk Trade Investment, Calabar, Nigeria.

Iwena, O. A. (2008). Essential Geography. Tonal Publishers Limited, Ibafo, Nigeria.

Jiao, N.Y., C. Zhao, T.Y. Ning, L.T. Hou, G.Z. Fu, Z.J. Li \& M.C. Chen. (2008). Effects of maize-peanut intercropping on economic yield and light response of photosynthesis. Chinese Journal of Applied Ecology, 19, 981-985.

Juo, A. S. R. (1979). Selected Methods for Soil and Plant Analysis. International Institute for Tropical Agriculture Manual Series, Number 1.

Keating, B. A. \& P.S. Carberry. (1993). Resource capture and use in intercropping: solar radiation. Field Crops Research, 34, 273-301. http://dx.doi.org/10.1016/0378-4290(93)90118-7

Marer, S.B., B.S. Lingaraju \& G.B. Shashidhara. (2007). Productivity and economics of maize and pigeonpea intercropping under rainfed condition in northern transitional zone of Karnataka. Karnataka Journal of Agricultural Science, 20, 1-3.

Mead, R. \& R.W. Willey. (1980). The concept of LER and advantages in yield from intercropping. Experimental Agriculture, 16, 217 -228. http://dx.doi.org/10.1017/S0014479700010978

Montha N. K. \& R. De. (1980). Intercropping maize and sorghum with soybeans. Journal of Agricultural science (Cambridge), 95, 107-112.

Montimere, M. J., B.B. Singh, F. Harris \& S.F. Blade. (1997). Cowpea in traditional cropping systems. In: Singh, B. B.; Morgan D. R.; Raji, K. E. \& Dashiell, K. E. (editors). Advances in Cowpea reearch. Pages 99-113. International Institute for Tropical Agriculture (IITA) and Japan International Research Centre for Agricultural Sciences (JIRCAS), Ibadan, Nigeria.

Mulongoy, M., K. Gueye \& R. Spencer. (1992). Biological Nitrogen Fixation and Sustainability of Tropical Agriculture. International Institute for Tropical Agriculture, Ibadan, Nigeria.

Murphy, J. \& J.A. Riley. (1965). A modified single solution for determination of P in natural water. Annals of Chemistry, 27, 31-37.

Nguimgo, K. A. B., V. Balasubramanian, F. Kaho \& P. Zonskeng. (2003). Maize-legume rotation and association for intensive maize production in the humid forest zone of Cameroun. In: Badu-Akraku, B.; Fakorede, M.; Ouedraogo, M.; Carsky, R. J. \& Menkir, A. (editors). Maize Revolution in West and Central Africa. Proceedings of a Regional Maize Workshop. International Institute for Tropical Agriculture, Cotonou, Benin Republic.14-18 May, 2001.

Odhiambo, G.D. \& E.S. Ariga. (2001). Effect of intercropping maize and beans on striga incidence and grain yield. Proceedings of the Eastern/Southern Africa Regional Maize conference, 7, 183-186.

Ofori, E. \& W.R. Stern. (1987). Cereal-legume intercropping systems. Advances in Agronomy, 41, 41-90. http://dx.doi.org/10.1016/S0065-2113(08)60802-0

Oko, B. F. D., M.G. Solomon \& M.Y. Bakoh. (1991). A note on the effects of planting date and plant density on the productivity of soybean in a humid tropical environment. Tropical Journal of Applied Science, 1, 38-41.

Okpara, D. A. \& B. Ibiam. (2000). Evaluation of soybean varieties for adaptability to a humid tropical environment in South Eastern Nigeria. Journal of Sustainable Agriculture and Environment, 2(1), 26-31.

Prasad, R.B. and R.M. Brook. (2005). Effect of varying maize densities on intercropped maize and soybean in Nepal. Experimental Agriculture, 41, 365-382. http://dx.doi.org/10.1017/S0014479705002693

Silwana, T. T., Lucas, E. O. \& Olaniyan, A. B. (2007). The effects of inorganic and organic fertilizers on the growth and development of component crops in maize/bean intercrop in Eastern Cape of South Africa. Journal of Food, Agriculture and Environment, (5)1, 267-272.

Sivaraman, K. \& S.P. Palaniappan. (1996). Cropping Systems in the Tropics-Principles and Management. New Age International Ltd., India.

Subbian, P., K.Annadurai \& S.P. Palaniappan. (2006). Agriculture, Facts and Figures. Kalyani Pubishers, New Delhi, India.

Ullah,A., N.A. Bhatti, Z.A. Gurmani \& H. Imran. (2007). Studies on planting patterns of maize (Zea mays L.) facilitating legumes intercropping. Journal of Agricultural Research, 45, 113-118. 
Table 1. Physical and chemical properties of the soils of the experimental sites in 2007 and 2008 late planting season at Akamkpa, South Southern Nigeria

\begin{tabular}{|l|l|l|}
\hline Properties & $\mathbf{2 0 0 7}$ & $\mathbf{2 0 0 8}$ \\
\hline Physical composition (g/kg) & & \\
\hline Sand & 10.0 & 5.0 \\
\hline Silt & 13.0 & 19.7 \\
\hline Clay & 77.0 & 75.3 \\
\hline Textural class & sandy loam & sandy loam \\
\hline Chemical characteristics & & \\
\hline pH $\left(\mathrm{H}_{2} \mathrm{O}\right)$ & 4.2 & 5.1 \\
\hline Organic carbon $(\mathrm{g} / \mathrm{kg})$ & 1.13 & 1.63 \\
\hline Total Nitrogen $(\mathrm{g} / \mathrm{kg})$ & 0.09 & 0.13 \\
\hline Available Phosphorous $(\mathrm{g} / \mathrm{kg})$ & 2.75 & 3.12 \\
\hline Exchangeable bases $(\mathrm{cmol} / \mathrm{kg})$ & & \\
\hline Ca & 0.6 & 2.2 \\
\hline Mg & 0.2 & 1.0 \\
\hline $\mathrm{K}$ & 0.07 & 0.08 \\
\hline Na & 0.04 & 0.05 \\
\hline Exchangeable Acidity (cmol/kg) & 4.8 & 3.0 \\
\hline ECEC (cmol $/ \mathrm{kg})$ & 5.71 & 6.33 \\
\hline Base Saturation $(\mathrm{g} / \mathrm{kg})$ & 16.0 & 53 \\
\hline & & \\
\hline
\end{tabular}

Table 2. Temperature and rainfall data at Akamkpa during experiment in 2007 and 2008

\begin{tabular}{|l|c|c|c|c|c|c|}
\hline \multirow{2}{*}{ Month } & \multicolumn{2}{|c|}{ Mean Temperature ( $\left.{ }^{\mathbf{C}} \mathbf{C}\right)$} & \multicolumn{2}{c|}{ Rainfall (mm) } \\
\cline { 2 - 7 } & \multicolumn{2}{|c|}{$\mathbf{2 0 0 7}$} & \multicolumn{2}{|c|}{$\mathbf{2 0 0 8}$} & $\mathbf{2 0 0 7}$ & $\mathbf{2 0 0 8}$ \\
\cline { 2 - 7 } & Min & Max & Min & Max & & \\
\hline August & 23.3 & 28.1 & 23.3 & 28.4 & 415.5 & 509.2 \\
\hline September & 23.7 & 28.7 & 23.4 & 29.7 & 561.7 & 122.5 \\
\hline October & 23.0 & 29.0 & 23.0 & 30.5 & 297.9 & 315.0 \\
\hline November & 23.0 & 30.4 & 23.7 & 31.6 & 263.2 & 102.5 \\
\hline December & 23.5 & 30.5 & 23.4 & 31.6 & 33.1 & 77.1 \\
\hline
\end{tabular}

Source: Nigeria Meteorological Services (NIMET), Calabar. 
Table 3. Effects of crop arrangement on mean cob length and cob diameter of intercropped maize in 2007 and 2008

\begin{tabular}{|l|c|c|c|c|}
\hline \multirow{2}{*}{ Crop arrangement } & $\mathbf{t}$ & \multicolumn{2}{|c|}{ Cobs length (cm) } & \multicolumn{2}{c|}{ Cob diameter (cm) } \\
\cline { 2 - 5 } & $\mathbf{2 0 0 7}$ & $\mathbf{2 0 0 8}$ & $\mathbf{2 0 0 7}$ & $\mathbf{2 0 0 8}$ \\
\hline $1: 0$ & $11.55 \mathrm{a}$ & $13.91 \mathrm{a}$ & $1.69 \mathrm{a}$ & $2.54 \mathrm{a}$ \\
$1: 1$ & $10.68 \mathrm{c}$ & $13.33 \mathrm{c}$ & $1.83 \mathrm{a}$ & $2.41 \mathrm{c}$ \\
$2: 2$ & $11.01 \mathrm{~b}$ & $13.56 \mathrm{~b}$ & $1.83 \mathrm{a}$ & $2.46 \mathrm{~b}$ \\
$1: 2$ & $11.27 \mathrm{ab}$ & $13.38 \mathrm{~b}$ & $1.83 \mathrm{a}$ & $2.45 \mathrm{~b}$ \\
$\mathrm{SE} \pm$ & 0.154 & 0.125 & 0.024 & 0.022 \\
\hline
\end{tabular}

$\mathbf{t}=$ maize: soybean. Means followed by a common letter in a column are not significantly different at 5 percent level.

Table 4. Effects of crop arrangement on mean number of cobs per plant and 100-grain weight of intercropped maize in 2007 and 2008

\begin{tabular}{|l|c|c|c|c|}
\hline \multirow{2}{*}{ Crop arrangement } & \multicolumn{2}{|c|}{ Number of cobs/plant } & \multicolumn{2}{c|}{ 100-grain weight (g) } \\
\cline { 2 - 5 } & $\mathbf{2 0 0 7}$ & $\mathbf{2 0 0 8}$ & $\mathbf{2 0 0 7}$ & $\mathbf{2 0 0 8}$ \\
\hline Sole maize & $0.95 \mathrm{a}$ & $1.07 \mathrm{a}$ & $17.17 \mathrm{a}$ & $21.86 \mathrm{a}$ \\
$1: 1$ & $0.86 \mathrm{c}$ & $0.99 \mathrm{c}$ & $16.50 \mathrm{a}$ & $20.35 \mathrm{c}$ \\
$2: 2$ & $0.91 \mathrm{~b}$ & $1.04 \mathrm{~b}$ & $16.73 \mathrm{a}$ & $21.18 \mathrm{~b}$ \\
$1: 2$ & $0.01 \mathrm{~b}$ & $1.04 \mathrm{~b}$ & $16.69 \mathrm{a}$ & $21.19 \mathrm{~b}$ \\
$\mathrm{SE} \pm$ & 0.011 & 0.011 & 0.21 & 0.28 \\
\hline
\end{tabular}

$\mathbf{t}=$ maize: soybean. Means followed by a common letter in a column are not significantly different at 5 percent level.

Table 5. Effect of crop arrangement on mean grain and cob yields of intercropped maize in 2007 and 2008

\begin{tabular}{|l|c|c|c|c|}
\hline \multirow{2}{*}{ Crop arrangement } & \multicolumn{2}{|c|}{ Grain yield ( kg/ha) } & \multicolumn{2}{c|}{ Cob yield (kg/ha) } \\
\cline { 2 - 5 } & $\mathbf{2 0 0 7}$ & $\mathbf{2 0 0 8}$ & $\mathbf{2 0 0 7}$ & $\mathbf{2 0 0 8}$ \\
\hline Sole maize & $1776.5 \mathrm{a}$ & $3221.0 \mathrm{a}$ & $2480.4 \mathrm{a}$ & $4002.0 \mathrm{a}$ \\
$1: 1$ & $1763.4 \mathrm{a}$ & $2941.0 \mathrm{~d}$ & $2474.8 \mathrm{a}$ & $2901.4 \mathrm{~b}$ \\
$2: 2$ & $1756.7 \mathrm{a}$ & $3110.3 \mathrm{~b}$ & $2473.5 \mathrm{a}$ & $3963.4 \mathrm{ab}$ \\
$1: 2$ & $1761.6 \mathrm{a}$ & $3070.5 \mathrm{c}$ & $2463.9 \mathrm{a}$ & $3945.0 \mathrm{ab}$ \\
$\mathrm{SE} \pm$ & 10.99 & 21.50 & 21.71 & 35.85 \\
\hline
\end{tabular}

$\mathbf{t}=$ maize: soybean. Means followed by a common letter in a column are not significantly different at 5 percent level. 
Table 6. Effects of crop arrangement on mean harvest index and shelling percentage of intercropped maize in 2007 and 2008

\begin{tabular}{|l|c|c|c|c|}
\hline \multirow{2}{*}{ Crop arrangement } & \multicolumn{2}{|c|}{ Harvest index } & \multicolumn{2}{c|}{ Shelling percentage } \\
\cline { 2 - 5 } & $\mathbf{2 0 0 7}$ & $\mathbf{2 0 0 8}$ & $\mathbf{2 0 0 7}$ & $\mathbf{2 0 0 8}$ \\
\hline Sole maize & $0.27 \mathrm{a}$ & $0.27 \mathrm{a}$ & $70.6 \mathrm{a}$ & $79.6 \mathrm{a}$ \\
$1: 1$ & $0.25 \mathrm{~b}$ & $0.26 \mathrm{~b}$ & $70.4 \mathrm{a}$ & $75.5 \mathrm{c}$ \\
$2: 2$ & $0.25 \mathrm{~b}$ & $0.26 \mathrm{~b}$ & $71.0 \mathrm{a}$ & $77.3 \mathrm{~b}$ \\
$1: 2$ & $0.25 \mathrm{~b}$ & $0.25 \mathrm{c}$ & $71.0 \mathrm{a}$ & $77.9 \mathrm{~b}$ \\
$\mathrm{SE} \pm$ & 0.016 & 0.002 & 0.33 & 0.34 \\
\hline
\end{tabular}

${ }^{\mathrm{t}}=$ maize: soybean. Means followed by a common letter in a column are not significantly different at 5 percent level.

Table 7. Effects of crop arrangement on number of pods per plant and percentage sterile pods of intercropped soybean in 2007 and 2008

\begin{tabular}{|l|c|c|c|c|}
\hline \multirow{2}{*}{ Crop arrangement } & $\mathbf{t}$ & \multicolumn{2}{|c|}{ Number of pods/plant } & \multicolumn{2}{c|}{ Percentage sterile pods } \\
\cline { 2 - 5 } & $\mathbf{2 0 0 7}$ & $\mathbf{2 0 0 8}$ & $\mathbf{2 0 0 7}$ & $\mathbf{2 0 0 8}$ \\
\hline Sole soybean & $36.05 \mathrm{a}$ & $45.43 \mathrm{a}$ & $25.12 \mathrm{c}$ & $23.75 \mathrm{c}$ \\
$1: 1$ & $32.79 \mathrm{c}$ & $33.63 \mathrm{c}$ & $33.73 \mathrm{a}$ & $31.15 \mathrm{a}$ \\
$2: 2$ & $30.61 \mathrm{~b}$ & $41.37 \mathrm{~b}$ & $28.69 \mathrm{~b}$ & $28.75 \mathrm{~b}$ \\
$1: 2$ & $31.05 \mathrm{~b}$ & $40.49 \mathrm{~b}$ & $28.45 \mathrm{~b}$ & $28.05 \mathrm{~b}$ \\
$\mathrm{SE} \pm$ & 0.989 & 1.024 & 0.539 & 0.486 \\
\hline
\end{tabular}

$\mathbf{t}=$ maize: soybean. Means followed by a common letter in a column are not significantly different at 5 percent level.

Table 8. Effects of crop arrangement on 1000-seed weight and seed yield of intercropped soybean in 2007 and 2008

\begin{tabular}{|c|c|c|c|c|}
\hline \multirow[t]{2}{*}{ Crop arrangement ${ }^{t}$} & \multicolumn{2}{|c|}{ 1000-seed weight (g) } & \multicolumn{2}{|c|}{ Seed yield (k/ha) } \\
\hline & 2007 & 2008 & 2007 & 2008 \\
\hline Sole soybean & $12.03 \mathrm{a}$ & $12.27 \mathrm{a}$ & $1617.9 \mathrm{a}$ & $1521.2 \mathrm{a}$ \\
\hline $1: 1$ & $12.26 \mathrm{c}$ & $11.99 \mathrm{c}$ & $1073.4 b$ & $817.2 d$ \\
\hline $2: 2$ & $11.83 \mathrm{~b}$ & $11.99 \mathrm{c}$ & $1120.7 \mathrm{~b}$ & $927.3 b$ \\
\hline $1: 2$ & $11.85 b$ & $12.06 \mathrm{~b}$ & $1117.0 \mathrm{~b}$ & $874.9 \mathrm{c}$ \\
\hline $\mathrm{SE}+$ & 0.9182 & 0.537 & 42.39 & 21.56 \\
\hline
\end{tabular}

$\mathbf{t}=$ maize: soybean. Means followed by a common letter in a column are not significantly different at 5 percent level. 
Table 9. Effects of crop arrangement on pod yield and shelling percentage of intercropped soybean in 2007 and 2008

\begin{tabular}{|l|c|c|c|c|}
\hline \multirow{2}{*}{ Crop arrangement } & \multicolumn{2}{|c|}{ Pod yield (kg/ha) } & \multicolumn{2}{c|}{ Shelling percentage } \\
\cline { 2 - 5 } & $\mathbf{2 0 0 7}$ & $\mathbf{2 0 0 8}$ & $\mathbf{2 0 0 7}$ & $\mathbf{2 0 0 8}$ \\
\hline Sole maize & $2092.7 \mathrm{a}$ & $2013.3 \mathrm{a}$ & $70.38 \mathrm{a}$ & $74.32 \mathrm{a}$ \\
$1: 1$ & $1567.7 \mathrm{~b}$ & $1292.3 \mathrm{~d}$ & $67.51 \mathrm{~b}$ & $72.16 \mathrm{c}$ \\
$2: 2$ & $1578.7 \mathrm{~b}$ & $1402.0 \mathrm{c}$ & $68.08 \mathrm{~b}$ & $73.43 \mathrm{~b}$ \\
$1: 2$ & $1580.4 \mathrm{~b}$ & $1354.6 \mathrm{~b}$ & $67.82 \mathrm{~b}$ & $72.83 \mathrm{bc}$ \\
$\mathrm{SE}+$ & 12.00 & 23.41 & 0.823 & 0.421 \\
\hline
\end{tabular}

$\mathbf{t}=$ maize: soybean. Means followed by a common letter in a column are not significantly different at 5 percent level.

Table 10. Grain yield, relative yield and relative yield totals for maize and soybean grown sole and in mixture in 2007, 2008 and 2007/2008 combined

\begin{tabular}{|c|c|c|c|c|c|}
\hline \multicolumn{3}{|l|}{ Grain yield } & \multicolumn{2}{|c|}{ Relative yield } & \multirow{2}{*}{$\begin{array}{l}\text { RYT } \\
\text { Maize/Soybean }\end{array}$} \\
\hline Arrangement & Maize & Soybean & Maize & Soybean & \\
\hline \multicolumn{6}{|l|}{2007} \\
\hline $2: 2$ & 1756.7 & 1120.7 & .99 & .69 & 1.68 \\
\hline $1: 2$ & 1761.6 & 1117.0 & .99 & .69 & 1.68 \\
\hline $1: 1$ & 1763.4 & 1073.4 & .99 & .66 & 1.65 \\
\hline Sole crops & 1776.5 & 1617.9 & 1.0 & 1.0 & - \\
\hline \multicolumn{6}{|l|}{2008} \\
\hline $2: 2$ & 3110.3 & 927.3 & .97 & .61 & 1.58 \\
\hline $1: 2$ & 3070.5 & 874.9 & .95 & .58 & 1.53 \\
\hline $1: 1$ & 2941.0 & 817.2 & .91 & .54 & 1.45 \\
\hline Sole crops & 3221.0 & 1521.2 & 1.0 & 1.0 & - \\
\hline \multicolumn{6}{|c|}{ 2007/2008 (combined analysis) } \\
\hline $2: 2$ & 2371.3 & 1024.1 & .95 & .64 & 1.59 \\
\hline $1: 2$ & 2416.1 & 956.0 & .97 & .60 & 1.56 \\
\hline $1: 1$ & 2357.2 & 945.5 & .94 & .59 & 1.53 \\
\hline Sole crops & 2498.8 & 1597.5 & 1.0 & 1.0 & - \\
\hline
\end{tabular}

RYT $=$ Relative yield totals. 